PSYCHOLOGIA ROZWOJOWA, $2017 *$ tom 22, nr 2, s. 33-42

doi:10.4467/20843879PR.17.008.7040

www.ejournals.eu/Psychologia-Rozwojowa

\title{
EWA SOKOŁOWSKA
}

Instytut Psychologii Akademia Pedagogiki Specjalnej, Warszawa Institute of Psychology Academy of Special Pedagogy, Warsaw e-mail: esokolowska@aps.ediu.pl

\section{GRAŻYNA KATRA, ANNA CIERPKA}

Wydział Psychologii Uniwersytet Warszawski, Warszawa Faculty of Psychology University of Warsaw

DOROTA TURSKA

Instytut Psychologii Uniwersytet Marii Curie-Skłodowskiej, Lublin Institute of Psychology Maria Curie-Sklodowska University

\section{Psycholog jako współkreator środowiska i procesu edukacyjno-wychowawczego}

\section{Psychologist as a Co-creator of the Environment and Educational Process}

\begin{abstract}
This article is an invitation to discuss the role and tasks of a contemporary school psychologist. The main purpose of the presented theory is to outline a school psychologist's role as a co-creator of the environment and educational process within the school setting. The introduced M-I-P-P model consists of the following psychological activities: Monitoring-Intervention-Prevention-Promotion. The need to constantly widen the possibilities of psychological action as well as to develop the ability to create autonomous plans of implementing those actions, are part of the described model. The understanding and accurate implementation of the presented model are key to the school psychologist's professional future, just as a clearly outlined and articulate professional identity is the necessary basis and regulator of one's functioning in the professional environment.
\end{abstract}

Keywords: education, school psychologist, professional identity, model of school psychological service.

Słowa kluczowe: wychowanie, psycholog szkolny, tożsamość zawodowa, model pracy psychologa w szkole. 


\section{WPROWADZENIE}

Sprostanie wyzwaniom współczesności przez kolejne pokolenia moga zapewnić odpowiednia edukacja oraz wychowanie. Wyzwania te są efektem postępu cywilizacyjnego i można je powiązać z globalizacją. Globalizacja oznacza przenikanie się kultur i ich upodabnianie się, $\mathrm{z}$ jednoczesną tolerancją dla odmiennych stylów życia. Zjawiska te wymagają od całych społeczeństw i poszczególnych jednostek akceptacji Innego (Bauman, 2000, 2007; Bauman, Tester, 2001), odmiennych stylów życia i różnych systemów wartości. Dyskusji nie podlegają prerogatywy moralne wynikające ze zdolności odróżniania dobra od zła, chociaż niekiedy właściwy moralnie wybór może stanowić wielkie - intelektualne i emocjonalne - wyzwanie. Kolejnymi istotnymi właściwościami współczesnego świata są jego zmienność i szybkość następujących po sobie zmian we wszystkich dziedzinach życia, określane przez Zygmunta Baumana (2007) jako płynna nowoczesność. Istnienie i godne przejście przez życie wymaga bycia kreatorem własnego losu, ale też zdolności i kompetencji niezbędnych do bycia wśród innych i podejmowania wyzwań wraz z innymi. Oznacza to potrzebę kształtowania u kolejnych pokoleń otwartej postawy i rozwoju kompetencji metapoznawczych, między innymi: zdolności do krytycznego myślenia, zdolności do planowania i realizowania swoich celów i zamiarów, do współpracy, efektywnego porozumiewania się, refleksji nad własnym postępowaniem i zachowaniami innych, w tym instytucji społecznych i politycznych (Katra, 2009; Ledzińska, 2012; Wosińska, 2011). Kompetencje te wydają się niezbędne do satysfakcjonującego życia w dzisiejszych czasach i w przyszłości, która jest coraz mniej przewidywalna. Wskazane wymogi współczesności powinny znaleźć swoje odzwierciedlenie w edukacji i wychowaniu, które odbywa się w rodzinie i w instytucjach powołanych do tego celu, czyli w placówkach oświatowych i wychowawczych. Zadania stojące przed oświatą znalazły swój wyraz w Deklaracji Globalnej Edukacji (2002)1 ${ }^{1}$, która głosi, że proces edukacji powinien mieć w centrum zainteresowania promowanie wartości prospo- łecznych i moralnych oraz przyjmowanie odpowiedzialności za siebie i swoje zachowanie. Środowisko i proces edukacyjno-wychowawczy znajduje się w obszarze zainteresowań psychologa wychowawczego. Podejście prezentowane w tym artykule wywodzi się z założenia, że rozwój jest wynikiem interakcji procesów dojrzewania oraz czynników pozabiologicznych, w tym przede wszystkim szeroko rozumianego wychowania (socjalizacji) oraz aktywności własnej podmiotu wychowywanego, będącej w bezpośredni i/lub pośredni sposób generowaną przez owe socjalizacyjne oddziaływania (Brzezińska, 2005; Grousec, Hastings, 2016). Warto przypomnieć, że w rodzimej literaturze przedmiotu oraz tradycji psychologiczno-pedagogicznej żywe jest odrębne ujmowanie kształcenia (nauczania) i wychowania (Kruszewski, 1998; Łobocki, 2008; Przetacznik-Gierowska, Włodarski, 1994; Włodarski, Hankała, 2004)2 . Kształcenie może być traktowane jako nabywanie i rozwijanie kompetencji w zakresie: komunikowania się, współpracy, samoregulacji w ramach uczenia się, kreatywnego myślenia, rozwiązywania problemów i konfliktów (por. Dembo, 1997; Kreator, 1996; Sędek, 2000). Wychowanie zaś może być rozumiane, jak proponuje Katra (2014), jako proces towarzyszący dojrzewaniu organizmu, zachodzący w niesymetrycznej interakcji pomiędzy wychowawcą a wychowankiem i prowadzący do rozwoju psychicznego jednostki. Wychowanie koncentruje się na funkcjonowaniu społecznym wychowanka, czyli rozwijaniu jego kompetencji społecznych, moralnych, a także na kształtowaniu zdolności do samoregulacji proaktywnej osoby wychowywanej. Samoregulacja proaktywna obejmuje umiejętność stawiania celów i ich skutecznego, ale i zgodnego z nakazami moralnymi i normami społecznymi realizowania. W tym ujęciu samoregulacja jest pojęciem szerszym niż samokontrola, wymaga zdolności do przekuwania zamiarów i intencji w cele, doboru środków ich realizacji oraz podejmowania rzeczywistych działań prowadzących do ich osiągnięcia. Wszystkie fazy samoregulacji proaktywnej wymagają zdolności do monitorowania swojej umysłowej i behawioralnej aktywności oraz rozwiniętej refleksyjności i po- 
czucia odpowiedzialności za siebie i za innych. Jak z powyższego wynika, samoregulacja jest stylem działania, który opiera się na rozwiniętych kompetencjach metapoznawczych oraz „meta-behawioralnych” (Kreator, 1996). Oba procesy - kształcenie i wychowanie - są ze sobą nierozerwalnie związane. W naszym podejściu koncentrujemy się na procesie wychowania.

\section{NOWE ZADANIA I WYZWANIA STOJĄCE WOBEC PSYCHOLOGA - TEORETYCZNE ZALOŻENIA MODELU}

Przedstawione przesłanki pozwalają ujmować rolę psychologa wychowawczego (szkolnego) nie tylko jako lekarza pierwszego kontaktu, ale także, a może przede wszystkim, jako eksperta i inicjatora oddziaływań wspierających rozwój jednostki. Wychowywanie dziecka ma przy tym prowadzić do ukształtowania osoby zdolnej do kreatywnego i podmiotowego funkcjonowania w dorosłości (Jurkowski, 2003). W ten sposób sformułowany cel wymaga od psychologa podejmowania roli współkreatora procesu wychowawczego, nie tylko usługodawcy. Takie ujmowanie roli psychologa wychowawczego opiera się na prawie do przyjmowania przez psychologa zewnętrznej perspektywy wobec systemu edukacyjno-wychowawczego. „Prawo" przyjmowania tej perspektywy jest osadzone we współczesnej wiedzy z zakresu psychologii rozwojowej i psychologii pozytywnej. Istotę zewnętrznej perspektywy stanowi analiza rzeczywistych rezultatów oddziaływań dydaktycznych i wychowawczych na terenie szkoły (szerzej w systemie oświaty) dla rozwoju osobowego dziecka i jego podmiotowości. Oznacza to, że psycholog wychowawczy jednocześnie należy i nie należy do systemu danej instytucji oświatowej. Należy, ponieważ jest zatrudniany na etacie psycholog-nauczyciel. Opisanie roli poprzez dodanie członu ,nauczyciel” powoduje, że psycholog podlega prawom i obowiązkom wynikającym z Karty Nauczyciela jako pracownik danej placówki edukacyjno-wychowawczej (Ustawa z dnia 26.01.1982, Dz.U. z 2016, poz. 1379). Nie należy - ponieważ obowiązuje go
Kodeks Etyczno-Zawodowy Psychologa i podstawowa misja jego zawodu - czynienie życia człowieka lepszym. W tym ujęciu wymagania systemu oświaty, na przykład zawarte w statucie szkoły, stoją na drugim miejscu i mogą być respektowane w zakresie, który nie koliduje z kodeksem etycznym. Psycholog nie może akceptować warunków pracy ograniczających jego niezależność zawodową, a zwłaszcza tych, które uniemożliwiają stosowanie zasad etyki zawodowej $^{3}$ (Bednarek, 2016; Fiutak, 2016; Kodeks etyczno-zawodowy psychologa, 1992).

Powinności psychologa obejmują obok monitoringu, to jest aktywnego śledzenia procesu wychowania $\mathrm{z}$ perspektywy wiedzy psychologicznej i rzeczywistych funkcji sytuacji wychowawczych, również podejmowanie aktywności określanych jako promocja i profilaktyka. Psycholog powinien inicjować i kreować różnorodne działania zmierzające do optymalizacji procesu edukacji i wychowania w środowisku szkolnym i rodzinnym. Oznacza to między innymi dbanie o atmosferę w szkole, integrację szeroko ujmowanej społeczności szkolnej, rozwijanie kompetencji wychowawczych, dbanie o rozwój zasobów uczniów i nauczycieli. Konkludując, psycho$\log$ nie powinien ograniczać się jedynie do reagowania na zgłoszone problemy, czyli do interwencji, z którą jest najczęściej kojarzony. Całość działań psychologa powinna się wpisać w model czteroelementowy: monitoring-promocja-profilaktyka-interwencja (model M-P-P-I) (rysunek 1).

Każdy z tych elementów wymaga szczegółowego opisania i przedyskutowania. Model

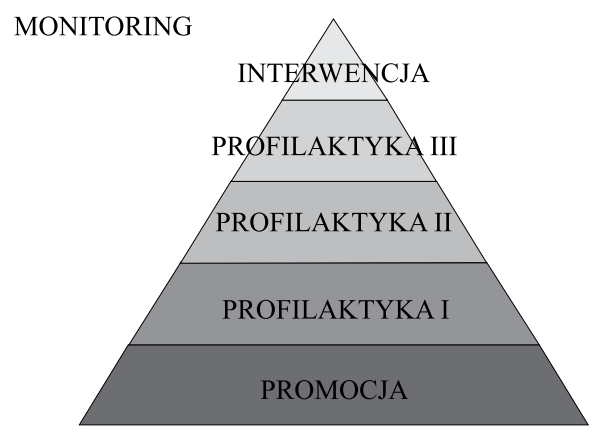

Rysunek 1. Model roli psychologa wychowawczego 
roli psychologa wychowawczego, w szczególności szkolnego, może mieć bowiem nie tyko zastosowanie praktyczne, ale także teoretyczne w konstruowaniu tożsamości zawodowej tej grupy psychologów.

\section{CHARAKTERYSTYKA PODSTAWOWYCH KATEGORII ODDZIAŁYWAŃ PSYCHOLOGA PODEJMOWANYCH \\ W ŚRODOWISKU I INSTYTUCJACH WYCHOWAWCZYCH}

Przedstawiany w artykule model pracy psychologa szkolnego (wychowawczego) powstał w Katedrze Psychologii Wychowania Wydziału Psychologii UW i następnie został włączony jako obowiązujący do zajęć dydaktycznych prowadzonych w ramach specjalizacji z psychologii wychowawczej. Obecnie omawiany jest również na specjalności psychologia wspierania rozwoju i kształcenia na APS w Warszawie i w ramach kursu z psychologii wychowawczej na UMCS w Lublinie. W model M-P-P-I można wpisać szczegółowe kategorie oddziaływań, z jakich może skorzystać psycholog w środowisku edukacyjno-wychowawczym, to jest: monitoring, promocję, profilaktykę i interwencję. Wstępnie scharakteryzowane zostały one w osobnej publikacji, po upływie kilku lat warto je jednak dookreślić i ponownie przywołać (por. Katra, Sokołowska, 2010). Wskazać można konkretne działania mieszczące się w ramach wymienionych modułów, a także ich przydatność w realizowaniu całości modelu. Uznanie owych czterech elementów jako ważnych pozwala, naszym zdaniem, na zmianę postrzegania roli psychologa wychowawczego oraz ograniczenie konieczności podejmowania w środowisku wychowawczym i instytucjach wychowawczych jedynie interwencji bądź diagnozy.

Monitoring jest podstawą wszystkich innych działań psychologa szkolnego: diagnozy, interwencji, działań profilaktycznych i promocyjnych. $Z$ tego powodu na rysunku 1 monitoring został wpisany w tło piramidy, jako jej naturalne „otoczenie”. Monitorowanie życia szkolnego w jego wszystkich przejawach może odbywać się pod kątem tego, jakie warunki do rozwoju mają uczniowie i jakie rzeczywiste konsekwencje psychologiczne powodują określone oddziaływania.

Istota monitoringu rozumiana jest $\mathrm{w}$ modelu jako obserwowanie przebiegu procesu wychowawczego. Cel stanowi wychwytywanie niekorzystnych zjawisk w procesie wychowania, w przebiegu interakcji wychowawczej, a funkcje - kontrola procesu wychowawczego i rozwoju dziecka w ramach podejmowanych oddziaływań promocyjnych, psychoprofilaktycznych i interwencyjnych. Przykładowe formy monitoringu stosowane przez psychologa obejmują między innymi: obserwację, ekspertyzę, monografię klasy, rozmowę indywidualną lub wywiad, spotkania z dziećmi (klasą), rodzicami, nauczycielami (rozmowa, ankieta, kwestionariusz).

Pierwszym, niejako bazowym, bo stanowiącym podstawę piramidy (por. rysunek 1), w omawianym modelu rodzajem działań psychologa szkolnego jest podejmowanie działań promocyjnych. Istotą promocji jest stwarzanie optymalnych warunków do rozwoju jednostki. Celem tego rodzaju działań psychologa w szkole jest wspieranie dziecka w rozwoju zgodnie z jego potencjałem i stwarzanie szansy wykorzystania jego zasobów. Zasadniczą funkcją promocji jest wykorzystanie możliwości dziecka; dostarczanie wzorów i modeli osobowych; podnoszenie kompetencji interpersonalnych; wzrost dobrostanu dziecka i jego wychowawców. Przykładowe formy promocji stanowią: kształtowanie środowiska wychowawczego; treningi; warsztaty; proponowanie wzorców (modelowanie).

Psychoprofilaktyka w modelu obejmuje podejmowanie działań zapobiegających pojawieniu się niekorzystnych dla rozwoju i funkcjonowania jednostki oraz jej otoczenia zjawiskom. Istota działań profilaktycznych w szkole utożsamiana jest $\mathrm{z}$ nastawieniem na zapobieganie ściśle określonym negatywnym zjawiskom w wychowaniu lub zachowaniu ucznia, które mają przeciwdziałać pojawieniu się niekorzystnych dla jego rozwoju skutków. Celem profilaktyki może być między innymi zapobieganie pojawieniu się błędów wychowawczych lub nieko- 
rzystnych dla rozwoju i funkcjonowania dziecka zjawisk, na przykład agresji między rówieśnikami, stresu szkolnego czy braku umiejętności otwartego komunikowania się. Funkcją tego oddziaływania psychologicznego jest podnoszenie kompetencji wychowawców; kształtowanie kompetencji interpersonalnych wychowanków; rozwijanie odporności na niekorzystne wpływy otoczenia; rozwijanie samoregulacji. Przykładowe formy profilaktyki obejmują między innymi: przekazywanie wiedzy o wychowaniu i rozwoju (nauczyciele, rodzice, uczniowie); udzielanie porady psychologicznej (konsultacja); praca z grupa - warsztaty, treningi (opracowywanie scenariuszy, prowadzenie i ewaluacja zajęć profilaktycznych). Istnieje przy tym utrwalony podział na profilaktykę pierwszo-, drugo- i trzeciorzędowa (Crone, Horner, Hawken, 2009; Gaś, 1998; Sęk, 2000).

Profilaktyka pierwszorzędowa, nazywana uniwersalna, adresowana jest do wszystkich uczniów; działaniami obejmuje się niezdiagnozowane grupy. Kojarzona jest ona z promocja zdrowia, czasem wręcz z nią utożsamiana, ponieważ adresuje się ją do dużych grup ryzyka dzieci i młodzieży, a czasem do całej populacji (z tego powodu na rys. 1 profilaktyka pierwszorzędowa sąsiaduje bezpośrednio z promocja). Irena Jelonkiewicz (2012) sugeruje, że nie jest proste odróżnienie oddziaływania, które nastawione jest ,tylko" na utrzymywanie zdrowia i zapobieganie patologii (cel owej profilaktyki), od oddziaływania nastawionego na rozwijanie i wspieranie zdrowia. W artykule przyjęliśmy, że profilaktyka pierwszorzędowa ma dwa główne cele: promocję zdrowego stylu życia oraz zmniejszanie zasięgu podejmowania zachowań ryzykownych. Profilaktyka drugorzędo$w a$, nazywana selektywna, skierowana jest do grup podwyższonego ryzyka (np. zagrożonych uzależnieniem), jej głównym celem jest ograniczenie wystąpienia dysfunkcji i umożliwienie wycofania się z zachowań ryzykownych. Profilaktyka trzeciorzędowa, nazywana wskazująca, adresowana jest do grup wysokiego ryzyka i oznacza konsultację terapeutyczną i resocjalizację - w rzeczywistości szkolnej polega często na wspieraniu procesu terapeutycznego realizowanego na zewnątrz. Może też stanowić etap, który zabezpiecza osobę przed koniecznością kolejnej interwencji (dlatego profilaktyka trzeciorzędowa sąsiaduje i styka się bezpośrednio na rys. $1 \mathrm{z}$ interwencją).

Do kojarzących się najbardziej z pracą psychologa działań zaliczana jest interwencja. Istotą interwencji jest podejmowanie działań korygujących zaistniałe nieprawidłowości w procesie rozwoju dziecka lub w procesie wychowania. Celem oddziaływań psychologa jest przywracanie korzystnych dla rozwoju i funkcjonowania wychowanka warunków wychowawczych. Funkcją interwencji jest przywrócenie równowagi; naprawianie błędów wychowawczych; korygowanie lub kompensacja negatywnych skutków wychowawczych lub rozwojowych. Przykładowe formy interwencji stanowią między innymi: psychoedukacja, indywidualnie dostosowana pomoc psychologiczna, praca systemowa w środowisku wychowawczym (szkoła, rodzina).

Prezentowany model przysparza trudności w momencie, gdy jest wdrażany praktycznie. Trudności te dobrze obrazują wyniki sondaży przeprowadzonych - (1) wśród uczestników II Kongresu Pedagogów i Psychologów Szkolnych, który odbył się 7-8 lutego 2008 roku w Warszawie, opisanego w osobnej publikacji (Katra, 2010) oraz (2) wśród psychologów szkolnych stosujących w swojej pracy model M-P-P-I (Cierpka, 2016, wystapienie na XXV Ogólnopolskiej Konferencji Psychologii Rozwojowej). Podobne znaczenie miały też głosy w dyskusji w trakcie dwugodzinnego seminarium „Psycholog jako współkreator środowiska i procesu edukacyjno-wychowawczego" na XXV OKPR. Sygnalizowano w ich ramach:

- trudność w pełnym zrozumieniu postawy „,przyjmowania perspektywy zewnątrzsystemowej";

- brak otwartości dyrekcji szkoły i nauczycieli na nowe propozycje psychologa, wykraczające poza ustalony społecznie program (kanon) oddziaływań;

- niechęć do podejmowania współpracy przez rodziców (niejasna kwestia tajemnicy zawodowej);

- brak wsparcia zewnętrznego dla psychologów szkolnych (superwizja, konsultacje). 


\section{ROLA PREZENTOWANEGO \\ MODELU M-P-P-I W BUDOWANIU TOŻSAMOŚCI ZAWODOWEJ PSYCHOLOGA WYCHOWAWCZEGO}

Rozważania o znaczeniu tożsamości zawodowej w pełnieniu roli psychologa szkolnego (wychowawczego) należałoby zaczać od zdefiniowania, co oznacza ten termin i jak my go rozumiemy.

Tożsamość zawodowa jest częścią/elementem czy aspektem tożsamości jednostki i odzwierciedla poczucie przynależności do określonej grupy zawodowej i - podobnie jak tożsamość indywidualna - składa się z co najmniej dwóch komponentów. Pierwszy komponent wiąże się z osobistym doświadczeniem i własną aktywnością zawodową, a drugi z nich - z przynależnością do grupy zawodowej. Tożsamość zawodowa grupowa jest wynikiem między innymi wyobrażeń na temat pełnionej roli zawodowej, które istnieją w danym społeczeństwie i jego kulturze (Knez, 2016). Współcześni teoretycy i badacze tożsamości zawodowej wskazują, że zawiera ona także wymiar odnoszący się do interakcji i relacji z innymi ludźmi, które są nierozerwalnie związane $\mathrm{z}$ danym rodzajem działalności zawodowej (Knez, 2016). Ten aspekt obejmuje na przykład: rozmowę lekarza z pacjentem, rozmowę z uczniem prowadzoną przez psychologa szkolnego czy rozmowę policjanta z przestępcą. Można ten aspekt określić jako skrypty specyficznych sytuacji, które są charakterystyczne dla danej profesji. Wszystkie te komponenty składaja się na tożsamość zawodową jednostki, która ukierunkowuje percepcję, interpretację i rozumienie sytuacji zawodowych, a następnie wyznacza realizację zadań immanentnie z nimi związanych.

W modelu tożsamości i kształtowania się identyfikacji zawodowej Ashfortha i jego współpracowników (Ashforth, Harrison, Corley, 2008) charakter tych kluczowych interakcji i relacji opiera się na dwóch dynamicznie ze sobą powiązanych elementach, wchodzących ze sobą w zależności. Podstawowy krąg stanowi jądro tożsamości zawodowej, które ma charakter poznawczy (stwierdzenia opisowe i przekonania oraz stwierdzenia ewaluatywne), jak również afektywny. Zawiera stwierdzenia ,jestem...", definiujące osobę poprzez wykonywany zawód (np. ,jestem psychologiem”). Towarzyszy mu stwierdzenie „o co dbam/co cenię”, które wskazuje, co jest ważne w wykonywanym zawodzie dla danej osoby (np. zasadniczą wartością jest dla mnie uczynienie życia drugiego człowieka lepszym). Trzeci element komplementarny obejmuje uczucia związane z wykonywaną rolą zawodową. Kolejny krąg stanowi zawartość tożsamości zawodowej, określająca konkretne zadania i obowiązki związane z aktywnością zawodową, które odzwierciedlają cenione wartości (,troszczę się o...”), cele (,chcę osiagnąć...”); przekonania (,wierzę w...”), zwykle wykonywane zachowania (,generalnie robię...") oraz wiedzę, zdolności i umiejętności (,,potrafię zrobić..."). Trzeci krąg tego modelu zawiera rzeczywiste czynności i działania realizowane $\mathrm{w}$ ramach roli zawodowej.

Zdaniem Ashfortha i współpracowników identyfikacja zawodowa może obejmować wymienione wyżej komponenty, od pierwszego, które stanowi jądro tożsamości zawodowej, poprzez pierwszy i drugi aż do postaci obejmującej wszystkie elementy łącznie z trzecim - behawioralnym. Struktura zawierająca wszystkie trzy składowe identyfikacji zawodowej odzwierciedla szerokie ujęcie analizowanego konstruktu.

Zależności pomiędzy poszczególnymi kręgami można także traktować jako proces, który polega na ich wzajemnym oddziaływaniu. Inaczej mówiąc, można przypuszczać, że wykonywanie określonych czynności w ramach roli zawodowej będzie zwrotnie sprzyjać budowaniu elementów z „niższego”, głębszego poziomu identyfikacji zawodowej.

Autorski model M-P-P-I wypełnia szerszą formułę tożsamości i identyfikacji zawodowej. Zawiera postulowane elementy i zakłada istnienie wzajemnego wpływu, ukazując sens pojmowania przez psychologa:

- przekonań (kieruje się Kodeksem Etyczno-Zawodowym i podejmuje uzasadnienia nadrzędności zawartej tu teleologii, czynienie życia człowieka lepszym, wobec doraźnej polityki placówki);

- wiedzy, zdolności i umiejętności (psycholog określa obszar niezbędnych kompetencji 
zawodowych, co między innymi implikuje decyzje o indywidualnie ustalonym programie podnoszenia kwalifikacji zawodowych);

- wartości (inicjuje oddziaływania wspierające rozwój jednostki);

- celów zawodowych (podejmuje działania w zakresie monitoringu, promocyjne, profilaktyczne i interwencyjne);

- zwykle wykonywanych zachowań (hierarchicznie określa działania zawodowe, wraz z precyzyjnie podanymi: celami, funkcją i formami tych oddziaływań).

Odwołując się do cytowanego stanowiska Kneza (2016), wydaje się, że istnieje odpowiedniość pomiędzy komponentami w tym ujęciu (osobiste doświadczenie i własna aktywność zawodowa (a); przynależność do grupy zawodowej (b)) a przedstawionym modelem Ashfortha i jego współpracowników (Ashforth, Harrison, Corley, 2008). Obie propozycje przyjmują, że osiaganie tożsamości zawodowej jest procesem, którego pożądany etap stanowi przeświadczenie: ,jestem psychologiem”, „ta rola zawodowa jest dla mnie ważna”, „mam wobec tego faktu pozytywne emocje". Aby jednak nastapiło rzeczywiste, a nie deklaratywne uwewnętrznienie waskiej formuły identyfikacji (Ashforth, Joshi, Anand, O'Leary-Kelly, 2013), należy zaproponować spójną dla środowiska treść aktywności zawodowej, będącej punktem odniesienia do osobistych doświadczeń (Knez, 2016), jak również kategorie działań przynależnych danej roli zawodowej.

Wydaje się, że nie wszystkie role zawodowe, między innymi psychologa szkolnego, są wystarczająco dobrze zdefiniowane. Gdy brakuje doprecyzowania treści roli, prawdopodobnie trudniej jest zbudować własną tożsamość zawodową. Jeżeli bowiem status danej grupy zawodowej, profesjonalne zadania i obowiązki nie są jasno określone w przestrzeni społecznej, trudniej jest osobie wykonującej dany zawód zbudować własną tożsamość zawodową.

Posiadanie skrystalizowanej tożsamości zawodowej nie jest tylko zagadnieniem teoretycznym, przekłada się bowiem na jakość pracy. Rezultaty badań potwierdzają związki tożsamości zawodowej $\mathrm{z}$ różnymi parametrami funkcjonowania $\mathrm{w}$ roli zawodowej oraz z dobrostanem jednostki (Johnson, Lord, 2010; Johnson, Morgeson, Ilgen, Meyer, Lloyd, 2006; Knez, 2016). Wykazano także związek pojęcia tożsamości z decyzyjnością, czyli zdolnością do podejmowania decyzji na polu zawodowym (Duffy, Sedlacek, 2007), zaangażowaniem (Dobrow, Tosti-Kharas, 2011) i zobowiązaniem wobec wykonywanego zawodu (Duffy, Allan, Autin, Bott, 2013). Tożsamość zawodowa daje poczucie sensu i ukierunkowania w zakresie swojej własnej aktywności profesjonalnej, zwiększa wytrwałość w pokonywaniu trudności oraz determinację w podejmowaniu wyzwań zawodowych. Pozwala ona jednostce na wykazanie zarówno swoich walorów i właściwości osobistych, takich jak: siła charakteru, zainteresowania i zaangażowanie, preferencje, podstawowe dążenia i cele życiowe, jak też uznawanych przezeń nadrzędnych wartości (Hirschi, 2012). To dookreślona tożsamość nadaje sens życiu i zaspokaja potrzebę rozwoju osobistego, które są ściśle związane $\mathrm{z}$ poczuciem dobrostanu osoby. Badania potwierdzają, że jasna, wyklarowana tożsamość zawodowa wiąże się z większym zaangażowaniem zawodowym, wyższymi osiągnięciami i większą satysfakcją zawodową (Luyckx, Duriez, Klimstra, De Witte, 2010). Osoby o wyższym poczuciu tożsamości profesjonalnej mają lepiej wyklarowane pojęcie „Ja” oraz posiadają tożsamość osiagniętą. Można zatem sformułować tezę, że wyklarowana, dookreślona tożsamość zawodowa sprawia, że jednostka lepiej funkcjonuje w roli zawodowej, lepiej wypełnia swoje obowiązki, mając równocześnie poczucie wyższej satysfakcji życiowej i dobrostanu.

Przedstawione rozważania pozwalają wskazać, że ukształtowana tożsamość zawodowa pełni następujące funkcje:

- buduje poczucie odrębności zawodowej i specyfiki roli;

- daje i/lub podtrzymuje poczucie autonomii i odpowiedzialności za decyzje i działania podejmowane $\mathrm{w}$ ramach zadań i obowiązków;

- stanowi bazę dla współpracy z innymi grupami zawodowymi i instytucjami, z którymi współpraca jest niezbędna lub pożądana (Hirschi, 2012; Knez, 2016). 
Tożsamość zawodowa psychologa stanowi z jednej strony (a) odpowiedź na oczekiwania społeczne dotyczące charakteru, jaki ma mieć udzielanie pomocy oraz (b) jest sposobem uwzględniania wartości cenionych $w$ kulturze (węziej środowisku szkolnym) podczas ustalania celów pracy $\mathrm{z}$ osobą potrzebującą (stosunek do innych ludzi). Z drugiej strony zaś jest (c) osobistą odpowiedzią każdego psychologa pracującego w szkole na pytanie kim jestem? (stosunek do siebie samego). Skoro ciagle istnieje wiele niejasności, jak powinien być ten zawód wykonywany w szkole i innych instytucjach wychowawczych, to model M-P-P-I może wprowadzić uporządkowanie w tym obszarze. Oznacza to, że model może być pomocny i użyteczny w:

- wyznaczaniu celów zawodowych;

- porządkowaniu działań i zadań;

- utrzymaniu właściwych proporcji w podejmowanych działaniach;

- określaniu obszarów współpracy z innymi podsystemami danej placówki edukacyjnej.

\section{PODSUMOWANIE}

Z naszych rozważań wyłaniają się dwa najważniejsze wnioski. Psycholog powinien wspierać wszystkich uczestników systemu szkolnego w wychowaniu i nauczaniu uczniów oraz uczestniczyć w kształtowaniu środowiska wychowawczego w taki sposób, aby uczenie się i rozwój osobowości wychowanków przebiegały w sposób optymalny. Nie powinien natomiast wkraczać w obszar i kompetencje wychowawców, nauczycieli, pedagoga szkolnego, ani przejmować ich zadań. Oznacza to w praktyce przyjmowanie zewnatrzsytemowej perspektywy wobec procesu wychowania i życia szkolnego oraz dyrekcji i grona pedagogicznego, czyli ocenianie i rozumienie rzeczywistych konsekwencji oddziaływań wychowawczych.

Istotna staje się także aktywna postawa psychologa wobec powierzanych mu zadań oraz celów koniecznych do realizacji na terenie danej placówki i kształtowania ich zgodnie ze współczesną wiedzą psychologiczną. Psycholog szkolny ma być nie tylko usługodawca, ale powinien także kreatywnie oddziaływać na środowisko szkolne. Opisany model może stanowić dla zatrudnionego w szkole psychologa podstawę określania indywidualnych celów i przyjmowanych rozwiązań w danym miejscu pracy, z uwzględnieniem możliwości i ograniczeń, jakie charakteryzują system szkolny. Może on stać się ramą dla sposobu myślenia o swojej roli w środowisku szkolnym, i dzięki temu dać psychologom szansę wzmocnienia tożsamości zawodowej.

Aby jednak ugruntować kreatywną, prorozwojową dla środowiska szkolnego funkcję psychologa, niezbędne wydaje się równoległe wprowadzenie zasadniczych zmian w ustawodawstwie. Obecnie uprawnienia decyzyjne, eksperckie czy zarządcze, które sugerowane są $\mathrm{w}$ modelu, nie są wpisane w rolę psychologa explicite. Przede wszystkim psycholog nie powinien być zatrudniany na etacie nauczycielskim jak jest obecnie praktykowane - i powinien mieć większą samodzielność zawodową. Uchwalona w 2001 roku Ustawa o zawodzie psychologa, nie została wdrożona w życie (m.in. brakuje jej aktów wykonawczych). Uregulowanie sytuacji prawnej pozwoliłoby na budowanie realnej samodzielności psychologa na terenie szkoły i utworzenie odrębnych wymagań formalno-zawodowych dotyczących tej funkcji.

Postulujemy zatem rozpoczęcie środowiskowej dyskusji na temat miejsca psychologa szkolnego we współczesnej polskiej oświacie oraz podjęcie szerszych prób wdrożenia modelu M-P-P-I do szkół. Zamierzamy także - jako zespół - koordynować badania empiryczne dotyczące między innymi oczekiwań wobec psychologa szkolnego i jego pozycji w społeczeństwie oraz stworzyć platformę do wymiany doświadczeń psychologów wychowawczych pracujących w szkole. Przeniesienie założeń teoretycznych na grunt opisanych powyżej konkretnych działań pozwoli, naszym zdaniem, dookreślić tożsamość zawodową psychologa szkolnego i jasno sprecyzować jego zadania we współczesnej polskiej szkole. 


\section{PRZYPISY}

${ }^{1}$ Deklaracja Globalnej Edukacji (2002) z Maastricht, 15-17 listopada. Definicja została pierwotnie sformułowana w trakcie dorocznego spotkania Global Education Week Network na Cyprze, 28-31 marca 2002.

${ }^{2}$ Kształcenie - edukacja - dotyczy sfery przekazywania wiedzy i nauczania, a wychowanie - kształcenia osobowości, stylu funkcjonowania, rozwoju moralnego. W piśmiennictwie anglojęzycznym nie ma odpowiednika pojęcia „wychowanie”. Terminy zbliżone lub pokrewne to angielskie: socialization, parenting, bringing up.

${ }^{3}$ Kodeks Etyczno-Zawodowy Psychologa, http://www.ptp.org.pl/modules.php?name=News\&file=arti cle\&sid=29, dostęp: 4.10 .2016 .

\section{BIBLIOGRAFIA}

Ashforth B.E., Harrison S.H., Corley C.G. (2008), Identification in organizations: An examination of four fundamental questions. Journal of Management, 34 (3), 325-374.

Ashforth B.E., Joshi M., Anand V., O’Leary-Kelly A.M. (2013), Extending the expanded model of organizational identification to occupations. Journal of Applied Social Psychology, 43, 2426-2448.

Bauman Z. (2000), Globalizacja i co z tego dla ludzi wynika. Warszawa: Państwowy Instytut Wydawniczy.

Bauman Z. (2007), Ptynne czasy: życie w epoce niepewności. Warszawa: Wydawnictwo Sic!

Bauman Z., Tester K. (2001), O pożytkach z watpliwości. Warszawa: Wydawnictwo Sic!

Brzezińska A.I. (2005), Psychologiczne portrety człowieka. Gdańsk: Gdańskie Wydawnictwo Psychologiczne.

Cierpka A. (2016), Charakterystyka podstawowych kategorii oddziatywań psychologa podejmowanych w środowisku i instytucjach wychowawczych. Warszawa: Niepublikowane wystapienie na XXV Ogólnopolska Konferencja Psychologii Rozwojowej, który odbyło się w Krakowie w dniach 16-18 czerwca 2016 roku.

Crone D.A., Horner R.H., Hawken L.S. (2009), Przeciwdziałanie niepożadanym zachowaniom w szkole. Program wzorców zachowania. Warszawa: PARPA.

Deklaracja Edukacji Globalnej (2002), Przyjęta przez Europejski Kongres Edukacji Globalnej w Maastricht, w dniach 15-17.11.2002 roku, https://www.coe.int/t/dg4/nscentre/GE/GE/GE-Guidelines/Global_Education_Guidelines_PL.pdf, dostęp: 30.09.2016.

Dembo M.H. (1997), Stosowana psychologia wychowawcza. Warszawa: WSiP.

Dobrow S.R., Tosti-Kharas J. (2011), Calling: the development of a scale measure. Personnel Psychology, 64, 1001-1049, http://eds-1a-1ebscohost-1 com-1ebsco.han.buw.uw.edu.pl/eds/pdfviewer/pdfviewer?vid=4\& sid=7d49e7a0-3cc7-47c1-986e-f13a60b108f1\%40sessionmgr4006\&hid=4202.

Duffy R.D., Sedlacek W.E. (2007), The presence of and search for a calling: Connections to career development. Journal of Vocational Behavior, 70, 590-601, http://ac-1 els-2cdn-1 com-1ebsco.han.buw.uw.edu.pl/ S0001879107000358/1-s2.0-S0001879107000358-main.pdf?_tid=96b974be-8bbd-11e6-b053-00000aacb361\&acdnat $=1475755887$ e 774b266e95a14ba229a22540e58dd2d.

Duffy R.D., Allan B.A., Autin K.L., Bott E.M. (2013), Calling and life satisfaction: it's not about having it, it's about living it. Journal of Counseling Psychology, 60(1), 42-52, http://content-1 ebscohost-1 com-1 ebsco.han.buw.uw.edu.pl/ContentServer.asp? $\mathrm{T}=\mathrm{P} \& \mathrm{P}=\mathrm{AN} \& \mathrm{~K}=2012-30618-001 \& \mathrm{~S}=\mathrm{L} \& \mathrm{D}=$ pdh $\&$ EbscoContent=dGJyMNLe80SeprQ4zdnyOLCmr06eprdSrqe4S7WWxWXS\&ContentCustomer=dGJyMPGvsE2xqrZPuePfgeyx43zx.

Fiutak A. (2016), Pomoc psychologiczna. Prawo i etyka w zawodach terapeuty i psychiatry. Warszawa: Wydawnictwo Difin.

Gaś Z.B. (1998), Psychoprofilaktyka. Procedury konstruowania programów wczesnej interwencji. Lublin: Wydawnictwo UMCS.

Grousec J.E., Hastings P.D. (2016), Handbook of socialization. Theory and research. New York, London: The Guilford Press.

Hirschi A. (2012), Callings and work engagement: moderated mediation model of work meaningfulness, occupational identity, and occupational self-efficacy. Journal of Counseling Psychology, 59(3), 479-485, http://dx.doi.org/10.1037/a0028949. 
Jelonkiewicz I. (2012), Stres a zdrowie młodzieży. Warszawa: Wydawnictwo Akademii Pedagogiki Specjalnej. Johnson R.E., Lord R.G. (2010), Implicit effects of justice on self-identity. Journal of Applied Psychology, 4, 681-695.

Johnson M. D., Morgeson F.P., Ilgen D.R., Meyer C.J., Lloyd J.W. (2006), Multiple professional identities: examining differences in identification across work-related targets. Journal of Applied Psychology, 2, 498-506. http://content-1 ebscohost-1 com-1 ebsco.han.buw.uw.edu.pl/ContentServer. asp? $=\mathrm{P} \& \mathrm{P}=\mathrm{AN} \& \mathrm{~K}=20289047 \& \mathrm{~S}=\mathrm{R} \& \mathrm{D}=$ bth \&EbscoContent=dGJyMNLe80SeprQ4zdnyOLCmr06ep65Sr6i4SbOWxWXS\&ContentCustomer=dGJyMPGvsE2xqrZPuePfgeyx43zx.

Jurkowski A. (2003), Specyfika i znaczenie społeczne psychologii wychowawczej. W: A. Jurkowski (red.), Z zagadnień współczesnej psychologii wychowawczej (12-26). Warszawa: Wydawnictwo Instytutu Psychologii PAN.

Katra G. (2009), Młodzież a globalizacja. W: A. Błachnio (red.), Globalizacja a jednostka (43-66). Bydgoszcz: Wydawnictwo Uniwersytetu Bydgoskiego im. Kazimierza Wielkiego.

Katra G. (2010), Psycholog szkolny w Polsce i w innych krajach. W: G. Katra, E. Sokołowska (red.), Rola i zadania psychologa we współczesnej szkole (11-20). Warszawa: Wolters Kluwer.

Katra G. (2010), Model roli psychologa szkolnego. W: G. Katra, E. Sokołowska (red.), Rola i zadania psychologa we wspótczesnej szkole (21-32). Warszawa: Wolters Kluwer.

Katra G. (2014), Status psychologa i pedagoga w placówce oświatowej i poradni psychologiczno-pedagogicznej. Warszawa: Niepublikowane materiały do wykładu.

Katra G., Sokołowska E. (red.) (2010), Rola i zadania psychologa we współczesnej szkole (59-73). Warszawa: Wolters Kluwer.

Knez I. (2016), Toward a model of work related self: a narrative review. Frontiers in Psychology, 7, 331, 1-13.

Kreator (1996), Materialy edukacyjne kreatora. Kraków: Dariusz Pasieka.

Kruszewski K. (1998), Sztuka nauczania. Tom 1. Czynności nauczyciela. Warszawa: PWN.

Ledzińska M. (2012), Młodzi dorośli w obliczu globalizacji. Szkice psychologiczne. Warszawa: Wydawnictwo Difin.

Luyckx K., Duriez B., Klimstra T. A., De Witte H. (2010), Identity statuses in young adult employees: Prospective relations with work engagement and burnout. Journal of Vocational Behavior, 77, 339-349.

Łobocki M. (2008), Teoria wychowania w zarysie. Kraków: Oficyna Wydawnicza Impuls.

Sędek G. (2000), Psychologia kształcenia. W: J. Strelau (red.), Psychologia. Podręcznik akademicki. Tom 3, 259-280. Gdańsk: Gdańskie Wydawnictwo Psychologiczne.

Wosińska W. (2011), Oblicza globalizacji. Sopot: Smak Słowa.

Sęk H. (2000), Społeczna psychologia kliniczna. Warszawa PWN.

Ustawa z dnia 26.01.1982, Dz.U. z 2016, isap.sejm.gov.pl/Download?id=WDU19820030019\&type=3.

Włodarski Z., Hankała A. (2004), Nauczanie $i$ wychowanie jako stymulacja rozwoju człowieka. WarszawaKraków: Oficyna Wydawnicza Impuls. 